\title{
Review
}

\section{In defense of charisma}

\author{
Vincent W. Lloyd \\ Columbia University Press, New York, 2018, x + 193 pp., \\ ISBN: 9780231183871
}

Contemporary Political Theory (2020) 19, S141-S144. https://doi.org/10.1057/s41296019-00312-4; published online 18 February 2019

Max Weber drew his concept of charisma - to a significant degree - from his theological contemporaries. But Weber left at least two key elements of the Biblical tradition behind. First, charisma came to be a matter of authority for Weber, and he posited it as the relationship between followers and a leader who is perceived to be 'extraordinary.' St. Paul, however, wrote of charisma as a potential gift within anyone, and not just in leadership, but in such things as giving, showing mercy, speaking in tongues, healing, and discerning spirits. Secondly, charisma in the Bible comes in a normative frame, while Weber pursued his 'value-free' methodology.

In this scholarly but truly readable new book, Lloyd pushes back on Weber and most of both popular and academic literature on charisma to assert the value of a normative investigation of charisma - extraordinary gifts that, he argues, lie within our 'neighbour, great-aunt or colleague' (p. 172). Lloyd maintains that, when the word 'charisma' is used in politics, 'it brings with it ambivalence, the sense that charisma might be a necessary evil' (p. 1). When used with regards to celebrity, it appears as mere entertainment. In self-help books, it takes on pragmatic purposes, as a means to win friends and influence people. What these three parts of dominant culture are missing, says Lloyd, is not just the potential nobility of charisma, but more importantly, the normative dimensions of charisma - how it might relate to the good, the true, and the beautiful. Lloyd specializes in philosophy of religion, religion and politics, and race, and these interests frame the book, always with the ends of social justice in mind.

In fact, the suspicion of many cultural theorists toward the concept of charisma is laden with secular assumptions and their accompanying hidden normative commitments. Charisma enchants people, and that makes the secularist nervous, as they reason that 'religion is inherently deceitful, unsightly, and morally suspect, and so is charisma' (p. 4). In this frame, charisma is only a manipulative tool to be demystified, a ruse to be unveiled for political-economic critique.

(C) 2019 Springer Nature Limited. 1470-8914 Contemporary Political Theory Vol. 19, S2, S141-S144 
Lloyd wants to move past the modern secular and the modern 'value-free' methodology and asks, 'What if we approach charisma with the full range of a normative palate?' (p. 4). This is his project to investigate the elusive human element within charisma by reflecting on the life of Moses and three works of twentieth-century American literature, demonstrating in the process that charisma can be both democratic and authoritarian. If authoritarian, it uses this power to enflame desire already in its followers by keeping mediation invisible and thus reinforces its own social advantage to the detriment of others. Authoritarian charisma solidifies the status quo, reifying existent hierarchies and inequalities, as followers cede their capacity for judgment to the leader. In contrast, democratic charisma invites its audience to see the layers of mediation that configure their desires, and helps them shape new desires that in turn enables them to become charismatic themselves. Democratic charisma is usually small scale and always contagious, and can be found in 'the neighbour, the cousin, the colleague' (p. 6) calling people toward justice.

Lloyd offers a simple but effective evaluative, conceptual framework that can be applied to any investigation of charismatic leadership. Charisma, says Lloyd, is about a certain mode of self-presentation, and insofar as it helps people see the mix of ordinary and extraordinary in themselves, it exposes what is deeply human. Insofar as it masks this, blessing the ordinary and isolating the extraordinary in one place, it fails the normative test. At heart, this is a truly ambivalent approach to charisma, and its democratic and authoritarian elements are ideal types that are never purely embodied in one person.

Lloyd argues that ordinary people have some level of charisma, but this is a virtue muffled by cultural and ideological forces. Democratic charisma reinstates this virtue in its audience, a claim that assumes people are naturally attuned to the good, the true, and the beautiful. Ultimately, normative charisma reveals humanness, a sort of inwardness marked by that divine image within people that defies any adequate representation. Most of popular and academic accounts of charisma ignore this, caught up in pursuit or critique of authoritarian forms of charisma.

One strength of the book is Lloyd's wariness about the role of media and representation - another dimension of charisma not pursued by Weber. Media creates distance, and especially mass media has intentions beyond that of social justice, becoming a catalyst for celebrity, and the promulgation of the ideology of the cultural elite as they seek to secure their power. But there is no charisma without some mediation, whether it is even just the human voice or the written word. The question for Lloyd is whether this mediation is openly addressed or obscured and mystified. Lloyd can seem too pessimistic about representation, as if it were always misrepresentation, inadequate to the ineffable of our humanity. At

S142 (c) 2019 Springer Nature Limited. 1470-8914 Contemporary Political Theory Vol. 19, S2, S141-S144 
times, too, his notion of 'the world' seems confined to a negative 'worldliness.' But the limits and contingencies of representation are also part of being human, part of our life as embodied creatures in a contingent world (Smith, 2014). Still, the focus on mediation is certainly apt and a key strategy of the book.

Lloyd takes his normative theory to an analysis of historical, literary, and cinematographic figures, beginning with Moses who, although encumbered with multiple layers of representation in religious text and film, is the paradigmatic charismatic figure. Lloyd suggests that although Moses' charisma appears authoritarian at first, especially when he is understood through the representation of Charlton Heston, the nation-builder hero of The Ten Commandments. But Moses was in fact a poor public speaker and marginal figure to his own community who displays evidence of the democratic kind of charisma as he reveals his own 'fleshy, imperfect, and ultimately quite ordinary' character (p. 44) while leading the people on a path to justice - a promised land he never sees himself. In effect, it is the revelation of the charismatic figure as a flawed human being that helps keep charisma in check. I would add that this is not only the profound inwardness of our humanity, but its finite and limited embodiment that in fact enables followers to identify with the charismatic.

The three central chapters of the book explore the mediation of charisma through three American literary texts, each focused on one of the themes of goodness, truth, and beauty. These texts also explore racial issues, as Lloyd wants to test the value of charisma for its ethical value in seeking justice. For goodness, Lloyd pulls back the layers on the lawyer Atticus Finch in To Kill a Mockingbird, comparing Finch to Gregory Peck's portrayal of him in the Hollywood film. For truth, Lloyd looks at Socrates and Martin Luther King, Jr. in a work of fiction called Dreamer that investigates King's life by imagining King had a double named Chaym Smith. Finally, in the chapter on beauty, Lloyd examines Sherman Alexie's fictional story of a Spokane Indian reservation's blues band, called Reservation Blues. In each chapter, Lloyd discerns where charisma displays either authoritarian forms that perpetuate old racial hierarchies and oppression or democratic forms that challenge the old views of the world and self and contagiously empower others to realize their own gifts.

I dare say my own dissertation would have taken a different slant if this book had been published a few years earlier. Lloyd offers a detailed analysis of the normative nuances that can be found in performances of charisma. The schema of authoritarian vs. democratic charisma may not be the only categories to explore within the presentation of charismatic authority, but they are certainly a fruitful place to start, as shown in Lloyd's multiple applications of his model. His central focus on mediation and its representations adds further value to the book, especially for investigations of charisma in the age of electronic media. For political theory,

(c) 2019 Springer Nature Limited. 1470-8914 Contemporary Political Theory Vol. 19, S2, S141-S144 S143 
this book offers a new, normative research program for those interested in understanding how political leadership, charisma, and their many layers of mediation interact, not just to uncover the mechanics of that charismatic matrix, but to investigate it and evaluate it for the sake of the common good.

\section{Reference}

Smith, J. K. A. (2014). Who's Afraid of Relativism? Community, Contingency, and Creaturehood. Baker: Grand Rapids.

Publisher's Note Springer Nature remains neutral with regard to jurisdictional claims in published maps and institutional affiliations.

Peter Schuurman

Redeemer University College, Ancaster, ON L9K 1J4, Canada

pschuurm@icloud.com 